JEMS (Jurnal Edukasi Matematika dan Sains), 8(1), 2020, 1-6

DOI: $10.25273 /$ jems.v8i1.5626

\title{
Literasi Statistik Siswa Berdasarkan Gaya Kognitif Field Dependent dan Field Independent
}

\author{
Fardatul Amalia, Junaidah Wildani, Mohamad Rifa'i
}

(C) 2020 JEMS (Jurnal Edukasi Matematika dan Sains)

This is an open access article under the CC-BY-SA license (https://creativecommons.org/licenses/bysa/4.0/) ISSN 2337-9049 (print), ISSN 2502-4671 (online)

\begin{abstract}
Abstrak:
Penelitian ini bertujuan untuk mengetahui profil literasi statistik siswa kelas IX ditinjau dari gaya kognitif field dependent dan field independent. Penelitian ini dilaksanakan di MTs Assa'adah II. Subjek penelitian sebanyak dua siswa yang terdiri dari satu siswa bergaya kognitif field dependent dan satu siswa bergaya kognitif field independent. Metode pengumpulan data yang digunakan yaitu melalui tes dan wawancara. Tes yang digunakan terdiri dari tes GEFT untuk mengelompokkan gaya koginitif siswa dan tes literasi statistik untuk memperoleh data profil literasi statistik siswa berdasarkan kemampuan matematika yang setara. Sedangkan, metode wawancara digunakan untuk memperoleh informasi mengenai proses siswa dalam mengerjakan soal. Berdasarkan hasil penelitian, siswa yang memiliki gaya kognitif field dependent kurang mampu membaca data dalam tabel, tidak mampu menentukan data yang akan disajikan ke dalam diagram batang dan tidak mampu menyajikan diagram batang dengan benar. Sedangkan, siswa yang memiliki gaya kognitif field independent mampu membaca data yang disajikan, mampu menentukan data yang akan disajikan ke dalam diagram batang dan mampu menyajikan diagram batang dengan benar.
\end{abstract}

Kata Kunci: Profil Literasi Statistik, Gaya Kognitif, Field Dependent, Field Independent

\section{Pendahuluan}

Globalisasi dan IPTEK muncul sebagai suatu yang tidak dapat dihindari dan berpengaruh

\begin{abstract}
:
This research aims to determine the statistical literacy profile of grade IX students in terms of the field dependent and independent field cognitive styles. This research was conducted at MTs Assa'adah II. The research subjects consisted of two students consisting of one student of dependent field cognitive style and one student of independent field cognitive style. Data collection methods used are through tests and interviews. The test used consists of the GEFT test to classify the students' cognitive styles and the statistical literacy test to obtain student statistical literacy profile data based on mathematical abilities that are equivalent. Meanwhile, the interview method is used to obtain information about the student's process of working on the questions. Based on the results of the study, students who have a field dependent cognitive style are less able to read data in tables, unable to determine the data to be presented in bar charts and unable to present bar charts properly. Whereas, students who have an independent field cognitive style are able to read the data presented, able to determine the data to be presented in a bar chart and be able to present a bar chart correctly.
\end{abstract}

Keywords: Statistics Literacy Profile, Cognitive Style, Field Dependent, Independent Field

Fardatul Amalia, Universitas Qomaruddin

fardatulamaliah2@gmail.com

Junaidah Wildani, Universitas Qomaruddin

junhaefishyi@gmail.com

Mohammad Rifa'i, Universitas Qomaruddin vianditrivai@gmail.com 
bagi kehidupan manusia. Indonesia berada dalam era informasi yang identik dengan era literasi yang menggambarkan kemampuan berinteraksi, berkomunikasi dan beraktualisasi (Irianto \& Febrianti, 2017). Dalam rangka itu, literasi menjadi sesuatu hal yang perlu dikembangkan pada berbagai bidang ilmu pengetahun.

Literasi merupakan salah satu kompetensi dasar yang harus dimiliki oleh setiap orang pada era revolusi industri 4.0 saat ini. Dengan penguasaan literasi yang baik, maka kompetensi yang lain akan dapat dikuasai dengan mudah. Namun, faktanya kemampuan literasi masyarakat Indonesia terbilang cukup rendah. Data skor PISA (Programme for International Student Assessment) tahun 2018 menunjukkan bahwa, Indonesia berada pada peringkat 72 dari 78 negara yang disurvei dengan nilai rata-rata 371 dibawah rata-rata nilai seluruh negara OECD (Organisation for Economic Co-operation and Development) yaitu 487.

Berdasarkan fakta tersebut, maka perlu upaya yang masif untuk meningkatkan kemampuan literasi masyarakat indonesia. Terlebih lagi era globaliasai saat ini, banyak berita atau informasi yang beredar diberbagai media yang belum terjamin kevalidannya. Masyarakat Indonesia perlu menyaring dan mengkaji kebenaran dari informasi yang diberikan.

Terdapat berbagai macam jenis literasi yang dibutuhkan untuk menunjang kompetensi diberbagai bidang, salah satunya adalah literasi statistik. Literasi statistik merupakan kemampuan seseorang dalam membaca, menganalisis dan menyajikan berbagai data (Takaria, 2015). Kemampuan literasi yang rendah dapat berpengaruh pada rendahnya literasi statistik yang dimiliki masyarakat utamanya siswa. Hal tersebut diperkuat dalam penelitian Maryati \& Priatna (2018) yang menunjukkan bahwa kemampuan literasi statistik siswa Madrasah Tsanawiyah masih rendah. Hal ini dapat dilihat pada membaca data, melakukan proses pengolahan data dan mempresentasikan hasil pengolahan data mengalami kekeliruan dalam menyelesaikan permasalahan.

Kemampuan literasi statistik dapat dipengaruhi oleh keterampilan berfikir siswa. Keterampilan yang dimiliki siswa cenderung berbeda-beda. Perbedaan setiap individu dapat diungkapkan dalam tipe kognitif yang dikenal dengan istilah gaya kognitif. Dengan demikian gaya kognitif dapat dikatakan sebagai cara atau ciri yang terdapat dalam diri seseorang dalam mengolah suatu informasi yang berhubungan dengan lingkungan sekitarnya dan setiap orang memiliki cara sendiri yang disukai dalam belajar.

Gaya kognitif yang dimaksud dalam penelitian ini hanya dibatasi pada gaya kognitif berdasarkan aspek psikologi yang terdiri dari gaya kognitif field dependent (FI) dan field independent (FD). Siswa yang memiliki gaya kognitif field independent memiliki kemampuan yang analitis, memiliki motivasi dalam dirinya sendiri dan lebih suka bekerja sendiri. Sedangkan siswa yang memiliki gaya kognitif field dependent memerlukan petunjuk yang lebih banyak untuk memecahkan suatu masalah, suka bekerja kelompok atau belajar bersama dan memerlukan motivasi atau dorongan dari orang lain atau ekstrinsik. Hal tersebut sesuai (dalam Komadoko \& Suherman, 2017) bahwa individu dengan gaya kognitif field independent lebih analitis dalam melihat suatu masalah dibandingkan dengan gaya kognitif field dependent.

Berdasarkan permasalahan yang telah dijabarkan di atas, maka tujuan penelitian ini adalah untuk mengetahui profil literasi statistik siswa yang memiliki gaya kognitif field dependent dan field independent.

\section{Metode}

Jenis penelitian ini merupakan penelitian deskriptif kualitatif yang dilakukan di MTs Assa' adah II Bungah Gresik. Subjek dalam penelitian ini adalah siswa kelas IX A MTs Assa'adah 
II yang bejumlah 36 siswa. Dari jumlah tersebut, dipilih dua siswa sebagai subjek penelitian masing-masing satu siswa yang mempunyai gaya kognitif ield dependent dan field independent.

Metode pengumpulan data yang digunakan pada penelitian ini adalah melalui tes GEFT, tes literasi statistik, dan metode wawancara. Metode tes GEFT digunakan untuk mengelompokkan siswa berdasarkan gaya koginitif. Jika rentang skornya $0 \leq x \leq 9$ maka masuk kategori gaya koginitif field dependent, sedangkan gaya kognitif field independent mempunyai skor $9<x \leq 18$ (Nikmatul Karimah, 2016).

Tes literasi statistik digunakan untuk memperoleh data tentang profil literasi statistik yang dimiliki siswa gaya kognitif field dependent dan field independent. Soal tes literasi statistik diambi dari soal PISA dan divalidasi oleh ahli. Sedangkan metode wawancara digunakan sebagai penguat dalam memperoleh informasi dari siswa tentang proses pengerjaan soal tes literasi statistik.

Adapun indikator literasi statistik yang digunakan dalam penelitian ini dapat dilihat pada Tabel 1 berikut:

Tabel 1. Indikator Literasi Statistik

\begin{tabular}{cl}
\hline No & \multicolumn{1}{c}{ Indikator Literasi Statistik } \\
\hline 1. & Menafsirkan data \\
\hline 2. & Menuliskan informasi yang diketahui dari data \\
\hline 3. & Mengelola data \\
\hline 4. & Menarik kesimpulan dari data \\
\hline 5. & $\begin{array}{l}\text { Menyajikan data dalam berbagai cara atau tampilan } \\
\text { alternatif }\end{array}$ \\
\hline
\end{tabular}

Pemeriksaan keabsahan data dalam penelitian ini menggunakan triangulasi teknik, yaitu membandingkan hasil tes literasi statistik dan hasil wawancara dari sumber yang sama pada subjek penelitian. Data yang diperoleh dari sumber yang sama dapat dikatakan kredibel, jika hasil tes dan wawancara saling bersesuaian. Data dalam penelitian ini dianalisis mengacu pada poses analisis data kualitatif yaitu reduksi data, peyajian data dan penarikan kesimpulan.

\section{Hasil dan Pembahasan}

Berdasarkan permasalahan dan metode penelitian yang telah diuraikan pada bagian sebelumnya, maka langkah pertama yang dilakukan adalah menentukan subjek penelitian. Subjek penelitian diperoleh dengan memberikan tes GEFT kepada semua siswa kelas IX A yang berjumlah 36 siswa. Dari hasil tes GEFT terdapat 11 siswa yang memiliki tipe gaya kognitif field dependent dan 25 siswa yang memiliki tipe gaya kognitif field independent. Hasil tes GEFT tersebut kemudian dikonsultasikan dengan guru matematika. Hasilnya, diperoleh dua subjek penelitian, dimana subjek yang dipilih adalah siswa yang dapat berkomunikasi dengan baik dan memiliki kemampuan matematika yang setara. Subjek penelitian teradpat pada Tabel 2 berikut:

Tabel 2. Daftar subjek penelitian

\begin{tabular}{cccc}
\hline $\begin{array}{c}\text { Kode } \\
\text { Siswa }\end{array}$ & $\begin{array}{c}\text { Skor } \\
\text { GEFT }\end{array}$ & $\begin{array}{c}\text { Tipe } \\
\text { Subjek }\end{array}$ & $\begin{array}{c}\text { Kode } \\
\text { Subjek }\end{array}$ \\
\hline NAR & 9 & FD & SFD \\
NZ & 16 & FI & SFI \\
\hline
\end{tabular}


Setelah subjek penelitian terpilih, kemudian peneliti memberikan tes literasi statistik dan dilanjutkan dengan wawancara terhadap proses pengerjaan tes literasi statistik siswa. Tujuan wawancara adalah untuk menyakinkan peneliti terhadap hasil tes literasi statistik yang telah dilakukan kepada siswa.

Hasil tes dan wawancara yang telah dilakukan tersebut digunakan untuk membuat profil siswa mengenai kemampuan literasi statistik berdasarkan gaya kognitif FI dan FD. Berikut ini adalah pembahasan tentang profil literasi statistik dua orang siswa MTS Assa'adah II Bungah Gresik:

\section{Profil Literasi Statistik SFD}

Perbandingan hasil tes literasi statsitik dan wawancara dari SFD dapat dilihat pada Gambar 1. berikut ini:

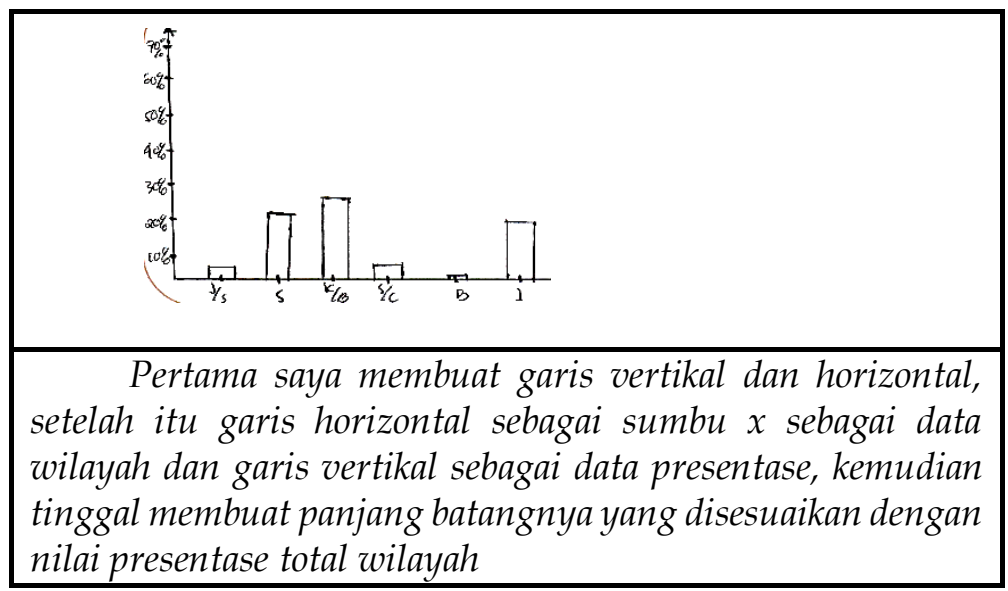

Gambar 1. Hasil tes literasi dan wawancara SFD

Jawaban tes tertulis dan wawancara tersebut menunjukkan sebuah informasi yang saling bersesuaian sehingga data tersebut dianggap kredibel. Sehingga data tersebut dapat dipakai untuk membuat profil seorang siswa.

Pada Gambar 1 tersebut dapat dijelaskan bahwa SFD mampu mengungkapkan informasi dari data akan tetapi tidak mampu menafsirkan dari tabel yang disajikan yaitu SFD hanya mengungkapkan kembali pertanyaan dan tidak mengungkapkan informasi-informasi yang terdapat dalam tabel yang disajikan. Selanjutnya, SFD tidak mampu mengelola data dengan benar, sehingga tidak dapat menentukan data untuk disajikan ke dalam diagram. Kemudian dalam menyajikan data, SFD menyajikan data dalam diagram batang yang berisi satu batang tanpa memberikan judul diagram serta tidak memberikan keterangan-keterangan di bawah garis horizontal dan di samping kiri garis vertikal.

Berdasarkan jawaban SFD tersebut, maka dapat disimpulkan bahwa SFD kurang mampu membaca data yang terdapat dalam tabel, tidak mampu menentukan data untuk disajikan ke dalam diagram batang sehingga tidak mampu menyajikan diagram batang dengan benar. Hal ini sesuai dengan penelitian Nikmatul Karimah (2016) yang menyatakan bahwa siswa yang memiliki gaya kognitif field dependent kurang teliti dalam menyajikan data dalam diagram batang. Sejalan dengan penelitian tersebut juga dalam Razak \& Sutrisno (2017) menunjukkan bahwa siswa yang memiliki gaya kognitif field dependent dalam menyajikan diagram batang memerlukan petunjuk yang lebih banyak. 


\section{Profil Literasi Statistik SFI}

Perbandingan hasil tes literasi statsitik dan wawancara dari SFI dapat dilihat pada Gambar 2. berikut ini:

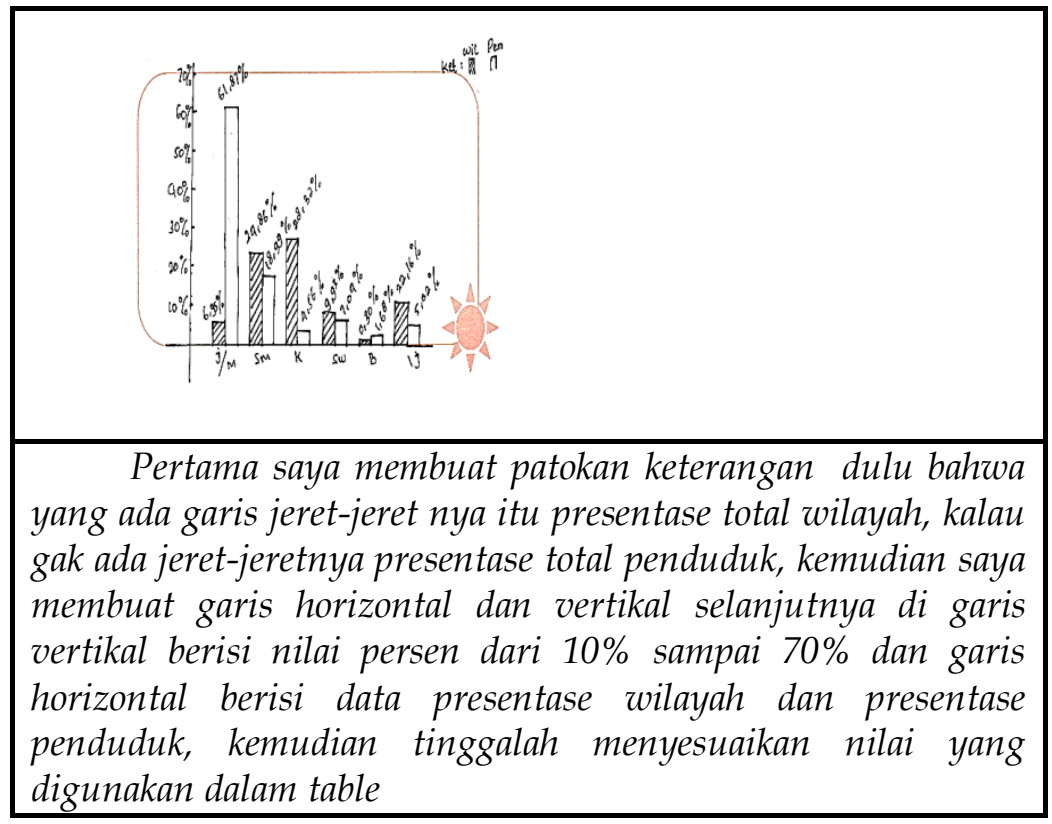

Gambar 2. Hasil tes literasi dan wawancara SFI

Jawaban tes tertulis dan wawancara tersebut menunjukkan sebuah informasi yang saling bersesuaian sehingga data tersebut dianggap kredibel. Sehingga data tersebut dapat dipakai untuk membuat profil seorang siswa.

Pada Gambar 1 tersebut dapat dijelaskan bahwa SFI mampu menafsirkan data dalam tabel yaitu menyebutkan informasi-informasi yang terdapat dalam tabel dan memahami pertanyaan yang disajikan. Selanjutnya, SFI mampu mengelola data dalam tabel yang disajikan sehingga dapat menentukan data untuk disajikan dalam diagram batang. Kemudian SFI menyajikan data dalam diagram batang, tidak menuliskan judul dalam diagram batang dan keteranganketerangan di bawah garis horizontal dan di samping kiri garis vertikal.

Berdasarkan jawaban SFI tersebut, maka dapat disimpulkan bahwa SFI mampu membaca data untuk disajikan dalam diagram batang sehingga mampu menyajikan data dalam diagram batang dengan benar. Hal ini juga sesuai dengan penelitian Nikmatul Karimah (2016) yang menjelaskan bahwa siswa yang memiliki gaya kognitif field independent mampu membaca data dengan teliti dan mampu menyajikan diagram batang dengan benar. Sejalan dengan penelitian tersebut penelitian Witkin (dalam Inayah, 2017) menunjukkan bahwa siswa yang memiliki gaya kognitif field independent mampu mengorganisasikan informasi secara tepat dan mandiri.

Dari berbagai penjelasan tentang profil literasi statistik tersebut, khususnya pada siswa kelas IX MTs Assa'adah II Bungah gresik terlihat bahwa SFI lebih unggul dalam menyelesaikan soal yang disajikan dibandingkan dengan siswa SFD. Hal tersebut sesuai dengan pendapat Nasution (dalam Rochmawati \& Hariastuti, 2017) bahwa siswa yang memiliki gaya kognitif field dependent sering gagal dalam mengisolasi informasi, sehingga memerlukan petunjuk yang lebih banyak untuk menyelesaikan suatu masalah. Sedangkan siswa yang memiliki gaya kognitif field independent lebih berhasil dalam mengisolasi suatu informasi data yang disajikan dan memproses informasi dengan kinerja yang lebih akurat. 


\section{Simpulan}

Profil literasi statistik siswa kelas IX A MTs Assa'adah II Bungah Gresik yang memiliki gaya kognitif field dependent adalah kurang mampu membaca data yang terdapat dalam tabel, tidak mampu menentukan data untuk disajikan ke dalam diagram batang dan tidak mampu menyajikan diagram batang secara benar. Sedangkan profil siswa yang memiliki gaya kognitif field independent mampu membaca data dalam tabel yang disajikan, mampu menentukan data untuk disajikan dalam diagram batang dan mampu menyajikan diagram batang dengan benar

\section{Daftar Rujukan}

Inayah, Nurul. 2017. The Influence of Mathematical Reasoning and Cognitive Style Towords Student's Comunication And Connection Ability to the Statistical Topic in Class XI Exact of Public Senior High School Palu. Jurnal Education. 5 (1): 122-123.

Irianto, O. P., \& Febrianti, Y. L. 2017. Pentingnya Penguuasaan Literasi Bagi Generasi Muda dalam Menghadapi MEA. Jurnal Education and Language International Conference Proceedings Center for Language Development of Unissula : 640-642.

Karimah, Nikmatul. 2016. Profil Literasi Statistik Siswa SMA Ditinjau Dari Gaya Kognitif Field Dependent dan Field Independent. Skripsi. Surabaya: Universitas Islam Negri Sunan Ampel Surabaya.

Komandoko, \& Suherman. 2017. Profil Intuisi Matematis Siswa dalam Pemecahan Masalah Matematika Ditinjau Dari Gaya Kognitif Field Independent dan Field Dependent. Jurnal Penelitian LPPM IKIP PGRI Madiun. 5 (1): 4.

Manik S. 2017. Netizen Indonesia, Angka Literasi, dan Maraknya Hoax. https://www. Kompasiana. com/ amp/maniksukoco/Netizen-Indonesia-Angka-Literasi-dan Maraknya-Hoax. Diakses tanggal 17 Maret 2019.

Maryati, I., \& Priatna, N. 2018. Analisi Kemampuan Literasi Statistis Madrasah Tsanawiyah dalam Materi Statistika. Jurnal of Mathematics Education IKIP Veteran Semarang. 2 (2).

Rochmawati, A., \& Hariastuti, H. R. 2017. Analisis Pemahaman Siswa Pada Pokok Bahasan Garis dan Sudut Berdasarkan Gaya Kognitif Field Independent dan Field Dependent. Jurnal Pendidikan Matematika \& Matematika. 1 (1): 4.

Takaria, J. 2015. Literasi Statistis dalam Pembelajaran Kolaboratif. Jurnal Pendidikan Matematika. 